\title{
Great unreported discoveries no. 163
}

It's good to talk...

\section{Mike Resnick}

When the team at Iowa State (or was it Nebraska?) came up with proof positive that plants feel pain, it made headlines not just that day, but for months thereafter. We have millions of people who became vegetarians because they didn't want animals to die just so they could fill their stomachs, and suddenly they discovered that everything they eat feels pain.

I found it fascinating. That's why I changed my major and went into botany - because I couldn't stop wondering: if plants can feel, what else can they do? Like, for example, can they think?

Of course, thinking in itself is a dead end, especially if you're rooted to one spot, unless you can communicate your thoughts, so that's what I really tried to specialize in. It's a good thing I knew how to get government grants, because I spent the first 14 years after getting my $\mathrm{PhD}$ without any hint of success.

I would talk to them. I would play them music. I would write messages in every known language and hold them up. I even brought in professors who could speak dead languages. All to no avail.

Undaunted - well, not very daunted anyway - I brought in psychics to see if they could form a bond with any of the plants in my lab. Still no luck.

I would put bees and butterflies in screened cages and explain to the flowers that if they wanted to reproduce, all they had to do was tell me, and I would release the insects and the process of regeneration could get under way. Nothing.

Finally I tied them into computers, exceptionally bright machines that could turn almost any signal, no matter how slight, how basic, how weak, how alien - into a spoken translation. All I got was silence.

I still remember the breakthrough. I'd just met and lost my heart to Bubbles La Tour, a truly wonderful dancer who, despite her billing, could hardly be called a stripper as she started out naked (and then got energetic). I walked over to one of the hybrid daisies in the lab and began plucking off its petals one by one, muttering "She loves me...she loves me not...she loves me..."

"Ouch!" said a strange voice.

I looked around the lab, but I couldn't see anyone.

After a moment I decided I had imag- ined it, and I pulled off another petal.

"Damn, that smarts!" said the voice again. "What did I ever do to you?"

"I beg your pardon?" I said, looking around and trying to spot the speaker.

"Begging my pardon is all very well and good," said the voice. "But you're denuding me. Are you going to disembowel me next?"

"Who said that?" I demanded.

"Whose limbs have you been pulling off?" the voice shot back.

I stared at the daisy, and suddenly I saw that it was still attached to the computer. I'd run my most recent experiment two days

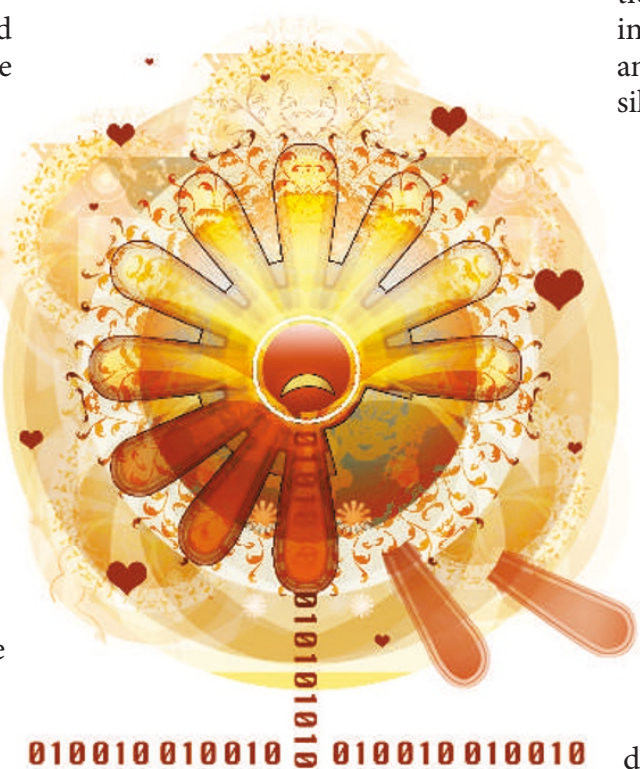

0100100100100010010010010

before and hadn't remembered to disconnect it.

"You?" I said, bending over it.

"Yes, me," said the daisy. "And brush your teeth if you're going to stand this close to me. I'm supposed to be living in a world of gorgeous scents."

"You can talk!" I exclaimed excitedly, and then repeated: "You can talk!"

"What a stunning observation," said the daisy. "You must have been the brightest one in your class."

“There's no need for sarcasm," I said.

"There's no need for sadism, either, but you kept pulling off my limbs."

"Your petals," I corrected it.

"Semantics," said the daisy.

"Well, now that I know you can talk, I promise never to do it again," I said.

"I don't want to seem ungracious, but how long have you known I could feel pain?"
"It got you to speak, didn't it?" I said defensively.

"So when your spouse is mad at you and won't talk, do you pull off her arms and legs?"

"Hardly ever," I admitted.

"Well, there you have it."

“Look, I apologize, all right?" I said. "This is the most historic breakthrough in the history of the human race! We should be celebrating!"

"Well, it's not the most historic breakthrough in the history of the daisy race," the flower replied. "I find you arrogant, self-centred, and a rather dull conversationalist. I am all through communicating with human beings now and forever, and I'm going to go back to peacefully and silently contemplating my navel."

"You don't have a navel," I pointed out.

"I was couching the concept in terms you'd understand, which was clearly a waste of time. Now please go away."

I spoke to it for another half an hour, but couldn't get any response. I considered calling in Doctors DiChario and Gormley, but then I did some serious thinking, and I decided that if the daisy kept its promise and didn't speak to them, they'd think I was either crazy or a liar (or both). And if it did speak to them, they'd apply for the same grants I was living on, and with their superior credentials they'd wrest them away from me and I'd have to go out and find another (and doubtless more difficult) way to make a living. If I tried to make my findings public and the daisy passed the word to its kith and kin, no one would be able to verify it and I'd become a laughing stock. And if the other flowers were as foul-tempered and obnoxious as the daisy, why would anyone want to communicate with them in the first place?

The more I thought about it, the more I decided that nothing is sometimes the very best thing to do.

I carefully disconnected the daisy from the computer.

Some time later I found myself thinking about Bubbles La Tour again, and my hand absently went to the flower.

"She loves me..." I intoned dreamily, "She loves me not..."

Five-time Hugo winner Mike Resnick is the author of more than $\mathbf{5 0}$ novels and 200 stories, and has edited more than 40 anthologies. He has won major awards in six countries, and his work has been translated into 22 languages. 